Graciela L. Ritacco de G.

Profesora en CIFHIRE-CONICET

Argentina

\title{
Los himnos theárquicos
}

"Recitad entre vosotros salmos, himnos y cánticos inspirados; cantad y salmodiad en vuestro corazón al Señor dando gracias continuamente y por todo..."

EP. EPH., 5.19-20

“...instruíos y amonestaos con toda sabiduría, cantad agradecidos a Dios en vuestros corazones con salmos, himnos y cánticos inspirados..."

EP. COL. 3.16

Muestro en este artículo la vinculación de Dionisio del Areópago con Proclo a propósito de un tema caro a ambos: los modos peculiares de exposición que adopta la teología (1). Proclo en las páginas iniciales de la Teología Platónica (Th.Plat.), escrita posiblemente en el final de su vida, refleja -de modo agudo y solemne a la vez-todos los aspectos para ser tomados en cuenta, pues aporta una cuidadosa distinción de los modos en que es trasmitida la teología. Como un eco, Dionisio los reelabora en el primer capítulo de Los Nombres Divinos (DN). Propongo esta cuestión como la preocupación casi excluyente del Areopagita, en diálogo velado con sus compañeros de estudio o tal vez sus maestros, últimos exponentes del platonismo en Atenas.

Se juegan, en el primer capítulo, una serie de temas interconectados como la vinculación de la teología con la sacralidad de sus fuentes reveladas. Cuestión relacionada con la cientificidad de la teología, su carácter dialéctico y, consiguientemente, la validez de sus premisas primeras. Tanto Dionisio como Proclo se detienen en la consideración del valor de la demostración. Pero, a partir de la célebre polémica de Porfirio con Jámblico (2), la teología misma -como saber de lo divino- es llamada a mostrar el alcance de su desempeño teórico.

(1) KALAITZIDIS, 'Theologia'. Discours sur Dieu et science Théologique chez Denys l'Arèopagite et Thomas d'Aquin “(en Denys l'Aréopagite et sa postérité en Orient et en Occident, Éd. de ANDYA, Paris, 1997, 457-501, en adelante DAP) dice expresamente que "en el Corpus Dionysiacum no hay ningún tratado o capítulo acerca del método teológico". Tesis que no comparto, pues cuando se lee a Dionisio con el trasfondo de la problemática filosófica helénica de los siglos III-VI d. C. son notorias las resonancias de las cuestiones debatidas en ese período. GOLITZIN, Et introibo ad altare Dei, The Mystagogy of Dionysius Areopagita, Thessalonikê, 1994, trata de equilibrar los aspectos filosóficos con el componente cristiano en el Areopagita mostrando los paralelos patrísticos que recorren la obra. 
Surge la pregunta acerca de qué aspecto predomina en Dionisio: ¿la vía filosófico-demostrativa o la vía simbólico-erótica? Como una paso hacia la solución rastreo la denominación de 'theárquicos' que Dioniso le aplica a los himnos.

El carácter iniciático y teúrgico de la palabra cultual -que canta himnos (3), ofrendándose como donación proveniente de la intimidad divina- resulta asumido por el conocimiento teológico. Dionisio no pierde de vista cómo se conjugan en el Verbo todos estos matices.

La 'veracísima teología', así llamada por Dionisio, es una peculiar puesta en práctica del conocimiento de lo divino, pues gracias a ella se despliega la cadena luminosa que une a Dios teúrgicamente. La filosofía 'epóptica' es un desarrollo de todo aquello que los dioses han trasmitido acerca de sí mismos. La ciencia que plasma los nombres divinos como imágenes opera de modo teúrgico. Se conforma de ese modo un cosmos mítico, exposición de la palabra sagrada. Salustio se concentra en la semejanza entre relato, significado, universo, iniciado y filósofo. En esa misma línea, el Anónimo Prolegómena a la Filosofía Platónica presenta al diálogo platónico como un universo.

Sin embargo, la cuestión tiene matices controvertidos. En un artículo reciente (4) G. Shaw resume buena parte de las polémicas en torno del momento teúrgico, considerado no racional, ateórico y, por ello, contrapuesto a la teología. El A. propone a Jámblico como antecedente de la manera en que Dionisio incorpora la teurgia dentro de su presentación cristiana. En opinión de este A. resulta inadecuada la oposición entre paganos y cristianos que suele mostrarse en torno al tema (5). Apoyándome en otros elementos, establezco algunas de las razones para sostener conexiones similares entre Dionisio y la filosofía griega de la Antigüedad tardía.

Sheppard (6), por su parte, ha mostrado, siguiendo a Rosan (7), que la teurgia tiene, para Proclo, por los menos dos valores: 1) un carácter subordinado, como

(3) Resulta muy sugestivo preguntarse por el valor litúrgico de himno en relación con la controversia abierta en torno al origen del alfabeto griego, pues una de las opiniones sostiene que, aunque tomó origen del alfabeto fenicio, el agregado de las vocales responde a la necesidad de mantener la sonoridad de la poesía con su verso (hexámetro) medido regularmente por la sucesión de una vocal larga y dos breves (dactilo). Véase WAD-GERY, The Poet of the Iliad, Cambridge, 1952; HAVELOCK, The Literate Revolution in Greece, Princeton, 1982; POWELL, Homer and the Origen of the Greek Alphabet, Cambridge, 1991; RAGUSSI, The Hellenic Alphabet, Web, issue EO (22-12-2001). El carácter sacro del alfabeto, vinculado a la iniciación, está conectado con los himnos en honor de Dioniso, según NONO DE PANÓPOLIS, Dionisíacas, IV, 255 ss: "Cadmo trajo a la Hélade entera dones con voz e inteligencia, al fabricar los instrumentos que representan los sonidos mismos de la lengua; mezcló consonantes (syzuga) y vocales (azuga) en un orden (stoichedon) de armonía connatural; dio forma a los caracteres gráficos (grapton), silenciosos y con voz a la vez; pues poseía la maestría de los misterios ancestrales, de un arte divino.(...) También trajo a la luz los ritos de Dionisio Egipcio, de Osiris errático, con el sonar de evohé. Pues había aprendido las ceremonias noctámbulas del arte iniciático. En secreto hacía sonar un mágico himno, con agitada voz y roncos sonidos" (traducción Manterola-Pinkler). La cadencia del movimiento, recogida por el canto, está bien explicada por BENVENISTE, 'La notion de 'rithme' dans son expresión linguistique' en Problèmes de Linguistique Générale I, Paris, 1966, 327-335.

(4) SHAW, 'Neoplatonic Theurgy and Dionysius the Areopagite', Journal of Early Christian Studies, 7 (1999) 4, 573-599.

(5) Lo conflictivo de esta tesis se destaca cuando se recuerda que LUTERO sostuvo que Dionisio "plus platonizans quam christianizans". En De Babyl. Capt. (1520).

(6) SHEPPARD, 'Proclus Attitude to Theurgy', Classical Quarterly 32 (1982) 212-224; Platos' Phaedrus in the Theologia Platonica, Proclus et la Théologie Platonicienne (Ed. Segonds-Steel), Leuven-Paris, 2000 (en adelante PTP). Véase también RAPPE, Reading Neoplatonism, Cambridge, 2000, especialmente pp. 178-180, 192. ROSAN, The Philosophy of Proclus, New York, 1949. 
ritual inserto en el mundo material; 2) un sentido superior -puramente contemplativo- al facilitar la unión con el Uno absolutamente trascendente (8). La A. se apoya en el comentario de Hermias al Fedro platónico, que me ha servido de punto de partida para una búsqueda en Dionisio del modo en que se hace presente en su obra este segundo sentido de 'teurgia'. 'Erôtikê mania', 'theia philosophia' y 'theourgikê dynamis' tienen un mismo significado para Proclo, según la A, pues son vías confluyentes para la consumación de la unión mística. Las virtudes 'teúrgicas' -que adornaron a Proclo de acuerdo con la Vida (26) escrito por su discípulo Marinos- aluden precisamente a la plenitud que deriva de la contemplación unitiva.

W

Comienzo con palabras de Dionisio del Areópago:

"Y a mí, me dé Dios el alabar con himnos (hymnêsai), de manera adecuada a Dios, las múltiples denominaciones (polyônymias), operantes de bondad (agatourgikas), de la divinidad indenominable e innombrable; y no quite de mi boca 'palabra de verdad' (Ps. 119, 43; II Tim. 2.15)" (9).

Tal como pide San Pablo en carta a Timoteo, recordando el salmo. Concluye así el primer capítulo del tratado acerca de los Nombres Divinos. Capítulo que, debido a su extrema complejidad, merece una consideración detenida, objeto de este artículo.

En mi opinión, con el primer capítulo de $D N$, Dionisio apunta a salvar la brecha que pueda abrirse entre teología y teurgia, problema que veladamente anuncia y responde a lo largo del capítulo. Propongo que el canto de alabanza, el himno en particular, es el puente que vincula la teología y la teurgia. El hecho mismo de elevar himnos (hymnein) a Dios permite acceder a las proximidades de 'la ciencia supraesencial', gozosa posesión del mismo Dios.

De modo expreso, Dionisio utiliza -casi exclusivamente- la palabra 'hymnos' en lugar de otros vocablos afines: 'psalmos', 'ôidê', 'proseuchê' o 'ainesis'. Repite la forma verbal 'hymnei' y algunos neologismos: verbos compuesto a partir de 'hymneô', una y otra vez, no solo en este capítulo sino a lo largo de todo el Corpus (CA) (10).

Como un probable antecedente en el uso de 'hymnos' por Dionisio se puede mencionar que en la versión de los $L X X$ se denomina 'himnos' a los salmos de

(8) El 'uno en el alma' es para Proclo un symbolon del Uno. La A. toma como punto de partida los tres tipos de poesía y tres clases de vida que distingue Proclo en el Comentario a la República (i.177 ss. Kroll). Puede verse RITACCO de GAYOSO, Del Alma a Dios, Mysterion Verbi, Bs. As. 1997, 221-239.

(9) Pseudo DIONISIO AREOPAGITA, Los Nombres Divinos (DN), I. 8. Utilizo la versión castellana de Cavallero en curso de publicación. Los textos griegos están tomados del Corpus Dionysiacum (SUCHLA-HEIL-RITTER) 2 vol., Berlin-New York, 1990-1991

(10) Del Thesaurus Pseudo-Dionysii Areopagitae (curantibus M. NASTA-CETEDOC, Lovainii Novi, 1993 ) resulta que el Corpus (CA) 'hymneô' está usado 107 veces, 67 en $D N$, en el primer capítulo aparece 16 veces.; 'hymnos' aparece 14 veces en el $C A, 7$ en $D N$; 'hymnologia', 9 en el $C A$ y 2 en $D N$; 'hymnôidia', 4 en $C A, 3$ en $D N$. 
David. 'Hymneô' aparece usado principalmente (36 veces) en Daniel 3, de acuerdo con la versión de los $L X X$ sabios. Filón de Alejandría, por su parte, llama 'hymnos' a los salmos del AT en todo momento (11). Agrega que la mejor acción que podemos ofrecer, como nuestro producto más perfecto y acabado, es un himno al Padre del universo (12). Además, para Flavio Josefo (13) (Ant.1.40), los cantos veterotestamentarios son 'hymnoi' (eis ton theon). Pero dentro del judaísmo de lengua griega no se distingue claramente entre hymnos-psalmos- ôidê (14)

Por otra parte, según Platón (15) el tipo de canto que llamamos 'himno' es una ofrenda a los dioses, "himnos a los dioses y encomios a los buenos", dice en Rep (607 a) (16). Los coros en las tragedias y en Aristófanes constituyen la principal fuente de información acerca de los himnos litúrgicos griegos, pues la lírica coral deriva del canto cultual (17). Para Elio Arístides (Or. 45.4 Keil) 'hymnos' designa el elogio en verso ofrecido a los dioses, distinto de cualquier otro discurso en prosa (18).

(11) FILÓN DE ALEJANDRÍA, Fug.59; Mut. Nom. 115; Som. 1.75; Conf. Ling. 52; Migr. Abr. 157. Los Salmos son los textos del AT más citados por Filón.

(12) FILÓN DE ALEJANDRÍA, Plant. 135; la mejor retribución a Dios por los dones recibidos es ofrendarle lo único que podemos darle: logois kai ôidais kai hymnois, en Sobr.58.

(13) Cf. DELling, 'Hymnos, psallô, psalmos', en KITTEL, Grande Lessico del Nuovo Testamento, 1984.

(14) Entre los primeros cristianos el canto antifonal del himno fue introducido por Ignacio en Antioquía, de donde se trasladó a otros lugares (SOCRATES, Hist. Ecclesiae, 6.8). Para EUSEBIO DE CESAREA (Hist. Eccl. 5.28.5) todos los psalmoi y las ôidai compuestos por los creyentes desde los inicios celebran (hymnousin) a Cristo como palabra de Dios.

(15) Los himnos tuvieron un papel muy destacado en la tradición pitagórica, DIOG. LAERT. 8.24. DEMÓSTENES, Or. 21.51 usa 'himnos' para referirse a los vaticinios oraculares; ARISTÓTELES, Po. 1448 b 27; EPICTETO, Diss. I.16; FILÓN DE ALEJANDRÍA, Ios. 253; Vit. Moy. 2.239; Conf. Ling.149; Corp. Herm. 13. 17-20; PLOTINO, Enn.II. 9.9.33; HIPÓLITO, Ref. 5.10.2 recoge el Himno de los Naasenos compuesto en metros griegos; véase M. MEUNIER, Hymnes philosophiques d'Aristote, Cléanthe et Proclus, 1935; PROCLUS, Hymnes et prières, traduction Saffrey, Paris, 1994.

(16) Los himnos son plegarias a los dioses (euchai pros theous), PLATÓN, Leyes, 700 b; el canto de himnos a los dioses y de alabanzas (hymnoi theôn kai enkomia) va unido a la plegaria; exige además que quien introduzca hymnoi diversos de los establecidos, sea procesado por asebeia 799 b; ibid. 801 d; Simp. 177 a; mythikos tis hymnos, Fedro, 265 c; Timeo 21 a y 26 e; Teéteto 175 e; Epinomis 980 b. Fedro 247 c 3 es evocado por Proclo en Th. Plat. IV.23.69. (Portus).

(17) Estos cantos cultuales de lengua griega fueron fijados por escrito recién en la época helenística. La mayor parte de los himnos mantiene una estructura que conserva una forma similar: invocación del dios, celebración de su nacimiento, sus obras, invocación de su venida.

(18) Resulta sugestivo que en una inscripción es llamado 'theologia' un discurso en prosa presentado ante una divinidad. W. JAEGER (Paideia, 2.1) describe muy bien el proceso: "Al mismo tiempo que la disolución de la forma épica en la prosa, que se realiza en este proceso creciente de historización de los mitos, se realiza otra transformación artística de los cantos heroicos en la poesía coral que surge en Sicilia: la transfiguración de la forma épica en la lírica. (...). Para la lírica coral anterior a Píndaro (esta transformación) no constituye un fin en sí, como ocurría con la épica, sino solo la materia ideal para las composiciones musicales y las representaciones corales. Logos, Rhithmos y Harmonía, cooperan en ellas, pero el Logos con menor importancia. La música orienta el conjunto y es la que despierta el verdadero interés. Es una disolución del mito en un número de momentos de sensibilidad lírica unidos a la progresiva narración, en forma de balada, con el solo objeto de servir de base a la composición musical. (...). Fácil es prever la evolución posterior de este proceso mediante la progresiva separación de las ideas relativas a una concepción del mundo en la nueva prosa filosófica y narrativa de los jonios, que desemboca en línea recta en la transformación de las formas poéticas, reflexivas y conceptuales, en los logoi parenéticos o científicos en prosa sobre areté, tyche, nomos y politeia, tal como los encontramos en la sofística”. 
El primer himno eclesiástico cristiano en versos griegos está conservado por Clemente Alejandrino (Paed. 3.101.3) (19).

Un caso interesante de la ofrenda de los himnos a Dios, en particular, se halla en Porfirio (20), cuando sostiene que a potencias diferentes han de ofrendarse diferentes tipos de sacrificios. Nada material se le ofrece al Dios supremo -dice Porfirio-, tampoco el lenguaje de la voz, ni siquiera el lenguaje interior. El único homenaje apropiado para Él es el silencio, que cumple la función laudatoria y unitiva del himno.

"Es preciso unirnos a Dios, hacernos semejantes a Él, ofrecerle nuestra elevación como un sacrificio sacro, porque ella (nuestra elevación) es nuestro himno y nuestra salvación. Este sacrificio se cumple en la impasibilidad del alma y en la contemplación de Dios. En cambio, para los retoños del Dios supremo, o sea para los dioses inteligibles, se debe agregar el himno de la palabra (ek tou logou hymnôdian). Puesto que el sacrificio es la consagración a cada divinidad de una parte de sus propios dones, aquella por la que la divinidad nutre nuestra esencia y la mantiene en el ser" (21).

Dionisio se esfuerza por probar que la palabra ofrecida como himno celebratorio (22) es ella misma el vehículo de la unión y el sustento de la ciencia teológica. Con la himnología cultual se cumple aquella deseada elevación de quien anhele reunirse con el Principio de la Deidad.

Para explicarlo, Dionisio llama "theárquicos" a los himnos. Expresión verdaderamente notable. Son calificados como 'theárquicos', en este primer capítulo, además de los himnos: el rayo de los sacros Oráculos, la bondad divina, las luces y la supraesencialidad misma, así como el equilibrio y la conexión (zygos) sostenidos por las potencias angélicas.

Si nos preguntamos por qué razón pueden recibir el predicado de 'theárchicos' tanto el rayo que fluye desde las palabras divinas pronunciadas en los Sacros Oráculos (hieroi logioi) -palabra revelada- como las luces que irradian desde ese luminosí-

(19) A partir del s. III se produce una cierta oposición al uso de himnos no bíblicos en la liturgia cristiana, prohibidos finalmente en el s. IV por el Concilio de Laodicea. En Oriente, sin embargo, no desaparecieron por completo. Finalmente fueron reemplazados por las llamadas 'Odas bíblicas' insertadas en códices griegos del siglo $\mathrm{V}$ en adelante.

(20) PORFIRIO, De Abstinentia, II.34. "Pitágoras etiam et noster Porphyrius religioso putant animum nostrum silentio consecrari”.; FIRM. MAT. Math. 7.1.1.

(21) Dei ara synaphthentas kai homoiôthentas autôi tên heautôn anagôgên thysian hieran prosagein tôi theôi, tên autên de kai hymnon ousan kai êmôn sôterian. En apatheiai ara tes psyches, tou de theou theôriai he thysia hautê teleitai. PORFIRIO, De Abst. II.34.

(22) HOFFMANN muestra la confluencia pagano-cristiana respecto de la oración filosófica, a propósito del comentario de Simplicio al De Caelo de Aristóteles". En même temps qu'il (Simplicio) offre au démiurge l'hymne du commentaire -et l'on sait qu'aux dieux seuls conviennent les hymnes- le philosophe écrit une prière à la première personne ... Le prière situe clairement le commentaire dans les perspectives anagogiques du cursus scolaire néoplatonicien, qui fait de l'activité philosophique une liturgie continuelle et une remontée spirituelle: le commentaire au $D e$ Caelo est une acte de conversión vers l'Intellect démiurgique, à travers l'expérience de la sympatheia avec le corps divin". (pp. 486-488) El. A. señala el paralelismo entre el aspecto telestético y el filosófico que Damascio, siguiendo a Platón, intenta consolidar (p. 475). En 'La triade chaldaïque erôs, alêtheia, pistis de Proclus à Simplicius', en PTP. 
simo rayo, o la bondad inherente a Dios mismo o su supraesencialidad, la respuesta es: son theárquicos porque forman parte de la intimidad divina. El rayo, la bondad, las luces constituyen un aspecto de su generosa donación. Han surgido desde su secretísimo y oculto abismo paternal, y precisamente por eso, son llamados 'theárquicos'.

Por lo tanto, fuera de Dios mismo, solo son 'theárquicos' el equilibrio angélico y los himnos, según el capítulo primero de $D N$.

Es sorprendente, desde luego, la referencia a los 'himnos' calificándolos como 'theárquicos'. La expresión aparece desde el primer capítulo del tratado en conjunción con el neologismo del que toma origen: 'thearquía': la Fuente de la divinidad (23).

La himnología, no cabe duda, es parte inherente de la revelación que Dios hace de sí mismo según el misterioso despliegue que opera la palabra orante, en el culto, al elevarse gozosa como celebración y alabanza, desde su proveniencia misma en los recónditos e insondables abismos divinos.

Dionisio aplica, a lo largo del Corpus Areopagiticum (CA), el predicado 'theárquico' (24) en múltiples oportunidades, sea a la sustancia misma de Dios, a los atributos divinos, a la actividad divina en relación con los hombres, a la Encarnación, a la presencia activa de Dios en el culto cristiano, al conocimiento de Dios, a la imaginería bajo la cual Dios es conocido, a la contemplación mística, al momento culminante del ascenso místico, a los sacramentos, a la Escritura. Pero es llamativo que solo en dos oportunidades predica de los himnos su carácter de 'theárquicos': en el primer capítulo de $D N$ (I.3), pasaje que estoy analizando en este momento y, en La Jerarquía Celeste (CH13.4), referido a los himnos seráficos.

Poco antes de concluir la $\mathrm{CH}$, hablando de la visión de Isaías (6, 1-8), Dionisio dice que el teólogo sacro (ho hieros theologos) es iniciado en la celebradísima himnología theárquica (tên thearchikên ekeinên kai polytimêton hymnôidian emystagôgeito) por el Serafín que le trasmite su propia ciencia sagrada (tês oikeias hierognôsias) (25).

La glorificación de Dios al adorarle con himnos es 'theárquica' cuando los himnos han surgido desde la intimidad misma de Dios, o del círculo más próximo a Dios, donde habita el Serafín. Al caracterizar algunos himnos como 'theárquicos' se impide que se independicen de su origen, exclusivamente divino. Los himnos son 'theárquicos' solo en conexión con Dios y con los Serafines, primer coro angélico, Fuego sagrado.

En otro pasaje, en $\mathrm{CH}$, (26) Dionisio muestra el estrecho nexo que conecta el conocimiento, en su funcionalidad teúrgica, con su proveniencia theárquica, desde las profundidades divinas. Se desliza así fácilmente desde la ciencia teúrgica (tas theourgikas epistêmas) a la ciencia theárquica (hê tês thearchikês epistêmês metalepsis) porque el rango theárquico, desde el interior de la intimidad de Dios, hace de la ciencia un logro teúrgico, en virtud de la iluminación (tas myêseis ellampesthai) brindada por la mismísima Thearquía.

(23) Por ejemplo en pseudo-DIONISIO AREOPAGITA, DN, I. 3; I.4; I.5; I.6;2.1; La Jeraquía Celeste $(\mathrm{CH})$ 2.1; 7.3. Es una pena que BERNARD ('La triple forme du discours théologique dionysien' en DAP, p. 504), cuando afirma que el vocablo 'thearchia' se encuentra ya en Atanasio y Gregorio de Nyssa, no proporcione la referencias.

(24) Véase LAMPE, Greek Patristic Lexicon.

(25) Pseudo-DIONISIO AREOPAGITA, $C H$ 13.4, Migne, $P G$ 3, 305 A.

(26) Ibid. 7.3 Migne, $P G 3.209$ A-C. 
Himnos y ciencia theárquicos abren la puerta para el banquete theárquico (27) (henopoiôi tês thearchikês hestiaseôs henotêti), en el que los coros angélicos más cercanos a Dios (Serafines, Querubines y Tronos) gozosamente danzan en torno del conocimiento de Dios (perichoreuousa tên aiônion autou gnosin), según la suprema estabilidad y constancia plenamente viviente (en angelois aeikinêton hidrysin), que sólo Dios mismo puede proporcionar.

Mientras los himnos theárquicos están en sede divina, la jerarquía eclesiástica canta, en cambio, salmos (he ton psalmon hierología) (28).

"La sagrada salmodia se une sustancialmente a casi todos los misterios jerárquicos" ante todo como celebración de la humana teurgia de Jesús (tas andrikas Iêsou teurgias) y, a la par, de la teología hipercósmica de Jesús (tên hypekosmion Iêsou theologian). Teurgia y teología aparecen aquí entrecruzadas, humana una -la teurgia-, supracósmica la otra -la teología-, ambas vivificadas en Jesús. El texto sagrado de las odas (he de tôn theiôn ôidôn hierographian) tiene por fin alabar con himnos (hymnêsai) toda palabra y toda acción divinas (theologias kai theourgias hapasas) y las hierologias y hierourgias humanas. Según esto, teología y teurgia se potencian mutuamente, se apoyan entre sí, son paralelas.

Pero, tras equiparar teología y teurgia, Dionisio afirma que el perfecto cumplimiento (he kata tautên telesiourgia) operado por el Nuevo Testamento es la teurgia que recapitula a la teología (hê theologias hê theourgia synkephalaiôsis) (29). La preeminencia teúrgica se basa, en este caso, en Dios mismo encarnado, el Logos que habitó entre nosotros.

El $C A$ tiene prácticamente un único tema: lo divino (30). Ocuparse de lo divino es la tarea de la ciencia llamada por los griegos: 'teología'. Si bien en las postrimerías de la Antigüedad, cuando los viejos dioses se iban desdibujando ante el auge del Cristianismo, se produjo una extraña simbiosis: se hizo filosofía a partir de los oráculos, mientras se presentó a la filosofía misma como una revelación (31). Dionisio redactaba sus obras cuando estos cambios alcanzaban su apogeo.

Poco o nada sabemos del autor del conjunto de tratados atribuidos a un cierto Dionisio del Areópago. En mi opinión, pertenece a la Escuela de Atenas, como discípulo cristiano de Proclo, hacia finales del siglo V d. C. (32).

(27) Ibid. 7.4, Migne $P G$ 3, 212 A.

(28) Pseudo-DIONISIO AREOPAGITA, La Jerarquía Eclesiástica (EH) 3.3.4, MIGNE, PG 3, 429 C$432 \mathrm{~A}$.

(29) Ibid. 3.3.5, 432 A

(30) LOUTH, 'Pagan Theurgy and Christian Sacramentalism in Denys the Areopagite', J. Theol. St 37 (1986), 432-438; RIST, Pseudo-Dionysius, Neoplatonism and the weakness of the Soul, en Westra (ed.) From Athens to Chartres, Leiden, 1992, 135-161; BELLINI, Teologia e teurgia in Dionigi Areopgita, Vetera Christ. 17 (1980),199-209; ROREM, Iamblichus and the Anagogical Method in Pseudo-Dionysian Liturgical Theology, St. Patr. 17 (1982), 453-460.

(31) HANKEY, W.J., 'Ad intellectum ratiocinatio...', Studia Patr. 29 (1997), p.245, citando a SAFFREY.

(32) Puede verse la introducción de SAFFREY a Proclo, Théol. Plat. I, Paris, 1968; I de ANDYA, Henosis, Leiden-New York-Köln, 1996 
Proclo, probablemente su antecedente más inmediato, además de dejarnos algunos comentarios de diálogos platónicos: al Timeo, al Parménides, a la República, al Alcibíades, escribió Elementos de Teología y una verdaderamente monumental Teología Platónica (33). Sobresale la denominación 'teología' entre los títulos de la obra de Proclo, preocupación central de la filosofía procleana, eminente filosofía de la mitología. Llamada por Vacherot filosofía 'alejandrina'. Dice Vacherot de ella:

"Los alejandrinos intentaron con cierto éxito transformar todo en ciencia: de los mitos hicieron Filosofía, de los procedimientos teúrgicos, Psicología y de las artes mágicas, Fisiología y Física" (34).

La filosofía así entendida es 'ciencia teológica'. Desde los tiempos de Pitágoras, alude a 'la sabiduría en asuntos divinos' (35).

Escuchemos algunas resonancias del ambiente espiritual próximo al paganismo en el que seguramente se desenvolvió el anónimo autor del $C A$, cuyo contenido principal es ante todo 'teológico'. Expondré un conjunto de textos afines a Dionisio, tomados principalmente del platonismo pitagorizante, debido a la extraordinaria afinidad de vocabulario, rastreable tanto en Dionisio como en la similitud de un pasaje a otro de estos autores del ocaso del mundo antiguo (36).

Apolonio de Tiana, un pitagórico de la época de Cristo, afirma:

"El método mejor y más verdadero de ofrendar un culto conveniente para la divinidad, culto que obtenga para nosotros el favor y la benevolencia de ese Dios que llamamos 'Primero', Dios único y separado del universo, sin cuyo concurso nos serían desconocidos los otros dioses, (el mejor culto) no es inmolar víctimas, ni encender el fuego, ni consagrarle nada de lo sensible ... sino hablarle siempre con el mejor de los lenguajes, esa lengua que no necesita de palabras, el pensamiento mudo, la inteligencia pura y sin órgano" (37).

Apolonio de Tiana destaca el corazón del conflicto: la disyunción o la integración entre rito y práctica religiosa, por un lado, o teología, con su proceder lógicointelectivo, por el otro.

Además, circulaba por entonces el vocablo 'teurgia', acuñado en griego, posiblemente en torno al siglo II d. C., en un medio próximo a la aparición pública de los Oráculos Caldeos. Alrededor de un siglo después irrumpió la preocupación por los Nombres de Dios, documentada en lengua griega casi con seguridad tras las huellas de Porfirio, a quien se le atribuye un Peri theiôn onomatôn, hoy perdido.

(33) Acaba de completarse (Paris, 1997) la edición de texto -que desde 1618 no se reeditaba- con traducción, notas y comentario de SAFFREY-WESTERINK en seis volúmenes.

(34) E. VACHEROT, Histoire critique de l'école d'Alexandrie, vol. II, Paris, 1846, p.146

(35) FILÓSTRATO, Vida de Apolonio de Tiana, Madrid, 1979, VIII.23.

(36) Cf. SAFFREY,'Un lien objectif entre le Pseudo-Denys et Proclus', Studia Patristica 9 (1966) 98105; 'Nouveaux liens objectifs entre le Pseudo-Denys et Proclus', R.Sc.Phil.Th. 63 (1979) 3-16; RITACCO de GAYOSO, 'Eros como nombre divino', Ethos, 12-3 (1984-5), 301-16.

(37) EUSEBIO DE CESAREA, Praeparatio Ev., 150, citado por VACHEROT, ibid. p.104. El texto de Peri thysias de APOLONIO tiene un equivalente en PORFIRIO, De Abst. II.34. Eusebio percibió el paralelismo de ambos pasajes y lo señaló expresamente. 
La teología y la teurgia se acoplan y se contraponen. Damascio en el comentario al Fedón (38) señaló expresamente que "Algunos estiman por sobre todo (protimôsin) a la filosofía, como Porfirio y Plotino, pero otros honran todavía más al arte hierático (hoi de tên hieratikên) como lo hacen Jámblico, Siriano, Proclo y otros hieráticos".

No cabe duda que Dionisio está al tanto de la cuestión (39) y por eso se sumerge en ella tal como aparece reflejado en el capítulo primero de $D N$.

El corpus, que ha llegado hasta nosotros, está compuesto por diez Epístolas, y los tratados: La Jerarquía Celeste, La Jerarquía Eclesiástica, Los Nombres Divinos y la Teología Mística.

Los dos libros que se ocupan de las Jerarquías, celeste y terrestre, tratan principalmente del aspecto litúrgico y sacramental, mientras que en $D N$ se desarrolla el tema de la nominación como vía afirmativa de conocimiento divino y en la Teología Mística $(M T)$ está expuesta la vía negativa junto con el silencio, que une a Dios en la Tiniebla mística. Tanto Sheldom Williams (40) como Vanneste (41) señalaron la dificultad para conciliar ambas vertientes: la sacramental y la cognoscitiva o dialéctica. Sobre todo porque entre los platónicos de la época se había planteado la polémica, reflejada por la disputa entre Porfirio y Jámblico, respecto de la importancia de las prácticas teúrgicas. Es una disputa acerca del carácter necesario del rito, tesis de Jámblico, o meramente complementario, tesis de Porfirio. La disputa está íntimamente conectada además con la concepción diversa del Alma en Plotino y en Jámblico.

Precisamente, mientras se estaba desenvolviendo el juego de oposición-yuxtaposición 'teología-teurgia', sale a luz -quizás a comienzos del s. VI d. C.- este conjunto de obras, preñadas de vocabulario mistérico, para referirse al Dios Uno-Trino (42).

Dionisio tematiza ante todo la dificultad que acarrea la referencia conceptual a un objeto que escapa a toda referencia. Las vías afirmativa y negativa se conjugan con la vía simbólica. Pero el peculiarísimo objeto divino requiere un tratamiento específico. La trascendencia divina impulsa hacia la vía anagógica. Dios mismo atrae hacia sí, en un proceso de comunión, que culmina como henosis, unión mística. En definitiva, la preocupación de Dionisio tiene que ver, de manera casi excluyente y principalmente, con la determinación del método mismo de aproximación a lo divino.

(38) En WESTERINK, The Greek Commentary in Plato's Phaedo, Amsterdam, Oxford, New York, 1977, ii. 1. 172.

(39) SCAZZOSO, 'La terminologia misterica nel corpus pseudo-areopagitico', Aevum 37 (1963), 406429; 'Rivelazioni del linguaggio pseudo-dionisiano intorno ai temi della contemplazione e dell'estasi', R.Fil. Neosc. 56 (1964), 37-66.

(40) SHELDOM WILLIAMS, 'The Pseudo-Dionysius', The Cambridge History of Later Greek and Early Medieval Philosophy (ed. ARMSTRONG), Cambridge, 1967, 457-472.

(41) VANNESTE, Le Mystère de Dieu, Paris, 1959; La théologie mystique du pseudo-Denys l'Aréopagite, Studia Patristica 5,3 (1962) 401-415.

(42) NASTA, 'Quatre états de la textualité dans l'histoire du Corpus Dionysien' (en DAP, 31-65) considera que "el examen crítico de los manuscritos más antiguos permite recuperar una imagen del texto trasmitida sobriamente, (...) verdadero despliegue esotérico de una tradición oral (kryphia paradosis)" (p.41). "El primer proyecto dionisiano , como se encuentra en Los Nombres Divinos, La Teología Mística y las cinco primeras Cartas, contenía lo esencial de su doctrina metafísica" (p. 37). Según el A., tanto en la Areopagitica como en S. Máximo, la Mystagogia es un templo sagrado, con su adyton y sus proporciones musicales ordenadas como las tonalidades de una escala. Referencias figurativas de una arquitectura sagrada aparecen en el metaforismo dionisiano (p. 31). 
Si Dionisio problematiza el tratamiento de lo divino, es en el interior de discusiones escolásticas, propias de la problemática neoplatónica (43), que se detuvieron a analizar las maneras en que Dios, como objeto de consideración teológica, es puesto en cuestión.

Cuando en la Epístola IX (1. 1105-1108) Dionisio distingue una dúplice tradición vigente en los autores sacros: una secreta y oculta, basada en los símbolos, cuidadosa del misterio; la otra, filosófica y demostrativa, está sintetizando el análisis exhaustivo de Proclo, para quien son cuatro las formas a las que recurrimos cuando se trata de mostrar lo divino, en lo que tiene de cognoscible por nosotros.

Proclo, con su gran capacidad para sistematizar el saber que lo precedió dejándonoslo como un legado, desgrana la sucesión de 'iniciaciones' que se completan y culminan con el 'divino Platón', en el libro primero de la Teología Platónica.

Despliega minuciosamente las diversas maneras en que Platón (44), su fuente de información, expuso ta mystika noêmata sobre los dioses.

Todo lo que tenga que ver con lo divino es susceptible de ser indagado por diversas vías de aproximación (ta gar theia kat' allon kai allon tropon hermêneuin dynaton) (45):

1) Entheastikôs (de manera inspirada),

2) dialektikôs,

3) symbolikôs,

4) apo tôn eikonôn.

Estas cuatro formas se agrupan de dos en dos ya que los modos de exposición teológica pueden ser indirectos o directos:

1) El modo indirecto, o sea la aproximación a la temática divina 'por indicios' (di' endeixeôs), comprende dos maneras de proceder:

a) symbolikôs/mythikôs

b) di' eikonôn.

2) El modo directo puede ser:

a) divinamente inspirado (katá tên ek theôn epipnoian)

b) propiamente científico o dialéctico (kat'epistêmên).

Entre estos diversos modos de exposición teológica se da una verdadera progresión o acrecentamiento, tanto en la sucesión histórica como en el creciente grado de profundidad en la penetración del tema, asegurando una, cada vez más perfecta, accesibilidad a lo divino, pasando por poetas o sacerdotes (di'onomatôn hieropre-

(43) Para PERCZEL ('Pseudo-Dionysius and the Platonic Theology' en PTP, p.507) el párrafo inicial de $D N$ es una combinación de elementos diversos que parafrasea PLOTINO, Enn VI.7.35, mediado por PROCLO, Th. Plat. I.1.3 y I.25, reescrito en términos paulinos.

(44) PROCLO, Th. Plat. I. 4. 17, cf. I.2.9; In Parm. (Cousin) 646-647; In Remp. I.84-85 (Kroll); II.8; también Anon. Proleg. 27, cuyo contenido es mayoritariamente procleano.

(45) PROCLO, In Parm. 646. 
pôn), ya se trate de Órficos, del pitagórico Filolao, o dialécticos (como la escuela Eléatica o Platón) (46).

El proceso de indagación de lo divino va desenvolviéndose y perfeccionándose según los cuatro momentos caracterizados por Orfeo, Pitágoras, los Misterios iniciáticos y, por último, Platón. Cada una de esas etapas está reproducida, a su vez, en la obra de Platón, quien recoge esos mismos momentos para llevarlos hasta su acabamiento con la dialéctica:

1) Lo divino es mostrado en primer lugar mediante los símbolos que apuntan a revelar los principios divinos relatados en los mitos (theomythias graphousin (47) / dia tôn mythicôn onomatôn (48)). Esta vía mítica (mythos, simple endeixis) consiste en describir la distribución (diakosmêsis) de los dones divinos al proporcionarnos todo aquello imprescindible para la vida humana. Es la forma propia de Orfeo. La forma 'simbólica' es utilizada por Platón en el Gorgias, el Banquete y el Protágoras.

2) Pitágoras introdujo una variación, sirviéndose de 'imágenes'. El pitagorismo utiliza las matemáticas como medio para favorecer la reminiscencia de los principios divinos. Con este procedimiento se enseña la procesión (proodos), los órdenes (taxis) y la demiurgia a través de términos matemáticos, éticos o físicos que operan como imágenes, di' homoiotêtos. El método icónico está aplicado por Platón en el Político y en el Timeo.

3) La manera 'divinamente inspirada' (49) corresponde a quienes tienen el rango más alto en la celebración de los Misterios. Consiste en una revelación de la verdad. Por esta vía se presentan los nombres de los dioses de acuerdo con la doctrina secreta de los Asirios (50). Aparece expuesta en el Fedro, donde Platón despliega los dioses intelectivos, encósmicos y las mónadas inteligibles separadas.

4) El modo 'científico-dialéctico', por último, corresponde a la filosofía de Platón. Solo Platón se preocupa por establecer las distinciones correctas, despliega la procesión de manera ordenada señalando tanto las diferencias mutuas entre los dioses como las propiedades que tienen en común (51). La

(46) Esta cuestión ha sido objeto recientemente de un conjunto de estudios complementarios que muestran la importancia y la complejidad del tema. GARCÍA BAZÁN, 'Le Dieu transcendant dans le neoplatonisme et chez Denys' (36-42), en Diotima, 23 (1995). En PTP: PÉPIN, 'Les modes de l'enseignement théologique dans la Théologie Platonicienne'(1-14); GERSH, 'Proclus'Theological Methods. The programmme of Theol. Plat. 1.4' (15-28); MOTTE, 'Discours théologique et prière d'invocation' (91-108); O'MEARA, La science métaphysique de Proclus comme exercise spirituel' (279-290); STEEL, 'Le Parménide est-il le fondement de la Théologie Platonicienne?' (373-398); van den BERG, 'Towards the Paternal Harbour' (425-444).

(47) Expresión usada en Th. Plat. I.4.10 referida a los Órficos.

(48) PROCLO, In Parm. I. 646.

(49) En In Parm. I. 647 es presentada como "hê (ephermêneusis) de tôn hieratikôn onomata tôn theôn kata tên eautôn mystikên hermêneian ekdedôkotôn".

(50) Ibid. 647.

(51) La descripción que proporciona PROCLO de la exposición dialéctica de los principios divinos contiene los elementos esenciales de la temática dionisíaca en $D N$ : "kai gar tên en taxei proodon tôn theiôn 
forma 'dialéctica' aparece ejemplificada en el Sofista y el Parménides, que se ocupan de la procesión del Ser a partir del Uno y de la trascendencia del Uno. La exégesis científica emplea los nombres dialécticos como 'uno y ser, todo y parte, lo mismo y lo otro, semejante y desemejante'. Estos nombres son los mismos que adjudica Dionisio a Dios cuando se ocupa de los Nombres Divinos.

La sucesión de métodos comprendidos por los modos de exposición de lo divino presentada por Proclo (52) finaliza con la dialéctica platónica, verdadera recapitulación que supera a los momentos anteriores. Platón es, para Proclo, quien ha logrado formular más acabadamente la 'dogmática' sobre los dioses.

Un lejano antecedente de esta clasificación se halla en la distinción de cuatro maniai, señaladas por Platón en el Fedro, como resulta del comentario de Hermias a este diálogo (53).

Dice Platón:

“...dijimos que el amor (eros) era como una locura, una manía... Pero hay dos formas de locura; una, debida a enfermedades humanas, y otra que tiene lugar debido a un cambio provocado por la divinidad en los usos establecidos (exallagês tôn eiôthotôn nomimôn). (...)

$\mathrm{Y}$ en la locura divina (theia mania) distinguimos cuatro partes que asignamos a cuatro dioses, atribuyendo a Apolo la inspiración adivinatoria (mantikên epipnoian), a Dionisos, la iniciática (telestikên), a las Musas, a su vez, la poética (poiêtikên), y la cuarta, la locura amorosa (erôtikên manian), que dijimos era la más excelsa, a Afrodita y a Eros" (54).

Puede agruparse las cuatro formas enunciadas en el Fedro -subsumidas bajo una división dicotómica (55)-: a) Apolo, secundado por las Musas, y b) Dionisos, con el séquito de Eros y Afrodita. Las cuatro formas de locura quedan agrupadas de dos en dos, resulta así:

1) la vía 'adivinatoria-poética' (mantikê epipnoia) regida por Apolo, y

2) la vía 'iniciática-erótica' (telestikê erotikê), tras las huellas de Dionisos

Epipnoia (inspiración) apolínea o Eros dionisíaco, según de cuál de ellos se trate, desencadenará un proceso de búsqueda y aproximación a lo divino. Se abren así las dos alternativas principales que se conjugan en el Corpus Areopagítico: la vía

genôn kai tên pros allêla diaphoran kai tas te koinas tôn holôn diakosmôn idiotêtas kai tas en hekastois diêirêmenas monos (...) kai dielesthai kai taxai kata tropon epecheirêse." Th. Plat. I.4.20.

(52) OPSOMER considera que estos modos de exposición teológicos (theologikês didaskalias) deben verse "as didactic rather than epistemic", "Deriving the three intelligible triads from the Timaeus', en PTP, p. 353.

(53) El comentario de Hermias es, en buena medida, una trascripción de las clases de Siriano sobre el diálogo.

(54) PLATÓN, Fedro 265 a-b (versión de L. Gil Fernández con modificaciones).

(55) Tal como muestra COLLI, en su bello libro La Sabiduría Griega, Madrid, 1995. Vimos anteriormente la división dicotómica de los métodos en directos e indirectos, según Proclo. 
teológico-demostrativa o la vía simbólico-erótica, como Dionisio distingue claramente en la Epístola IX (56).

Dionisio, a mi modo de ver, tiene muy presente esta célebre clasificación platónica, extraída del Fedro en torno de las theiai maniai, tan ligada a la profundización de la 'erótica', en Plotino, Hermias, Proclo y algunos Padres como Orígenes, los Capadocios, Agustín, el mismo Dionisio y sus prolongaciones medievales y renacentistas.

La catalogación de las formas de locura en Platón proporciona el criterio necesario para evaluar la idoneidad y la eficacia de cada uno de los métodos empleados para ocuparse de lo divino, puesto que otorga validez, no solo a la reflexión teórica (Logos) en torno de Dios, sino también a otras metodologías igualmente válidas no excluyentemente 'lógicas'.

A partir del Fedro es posible establecer un criterio de evaluación. Pero una vez elaborada la distinción entre los procedimientos resulta inevitable la pregunta por la superioridad o no, de alguno de esos métodos sobre otros.

De acuerdo con el Fedro platónico pareciera que la theia mania halla su culminación en el frenesí erótico, compatible con la inspiración iniciática (telestikê) provocada por Dionisos. Al seguir esta línea, la $M T$ aparece como el estadio final de la obra del pseudo-Dionisio, concluyendo en un momento místico-unitivo, más allá de la teología afirmativa propia de la nominación divina e incluso más allá del momento dialéctico negativo. Operaría en este caso la fuerza teúrgica del símbolo de una manera más efectiva que la intelectualidad de la demostración. El corpus areopagítico alcanza su acabamiento, en ese caso, con la $M T$, brevísimo tratado que remarca la importancia de la teología negativa, tras la afirmativa, expuesta en $D N$. El título de la obra: 'Teología Mística' es una verdadera contradicción en los términos. Apunta y tiende a la consolidación de la vía unitiva, pero recibe la denominación de 'teología', que pareciera responder más bien a una búsqueda intelectual y teórica, cuyo objeto, 'lo divino' -si fuera considerado solo de modo racional-, redundaría más bien en un alejamiento del momento verdaderamente unitivo.

Sin embargo, la enumeración de Proclo, que acabo de exponer anteriormente, pareciera sugerir que en lugar de ser el momento 'erótico' el punto culminante como en el Fedro platónico, los diversos métodos tienen su apogeo, más bien, en la manera 'dialéctica' que ocupa, para Proclo, el último puesto.

Ahora bien, si la dialéctica es el momento culminante, el éxtasis erótico-dionisíaco del Fedro platónico resultaría desplazado a un segundo lugar. El momento dialéctico es el coronamiento de la búsqueda inspirada por la theia mania en consonancia con la mantikê epipnoia de Apolo. Esto se reflejaría, en la obra de Dionisio, a través del predominio de la vía afirmativo-demostrativa de los Nombres Divinos, puesta ahora por encima del camino unitivo de la $M T$. DN pasaría a ser el tratado ‘dialéctico', momento final de la exploración teológico-dialéctica sobre lo divino.

(56) Puede verse la misma problemática en Proclo: "The Republic Commentary suggests a distinction of at least two levels within the category of the symbolic, the higher of which corresponds to the entheastic. Thus the conclusión seems unavoidable that (a) when Proclus considers Plato alone as theologian, he ranks the entheastic mode of exposition above the symbolic; and (b) when he considers Plato and Homer together as theologians, he allow the entheastic and symbolic modes of exposition to coincide". GERSH, en PTP, p.18. 
Sin embargo, según el comentario de Hermias, una es la teurgia aplicada a los asuntos de la vida y otra es la teurgia ritual, aplicada al alma en su ascenso. Para que pueda consumarse el ascenso se requiere que las cuatro maniai se combinen amorosamente (erôtikôs), continúa Hermias (57).

Llegados a este punto me pregunto si la vía erótica-unitiva de Dionisos es totalmente diferente y ajena a la manía poético-dialéctica inspirada por Apolo y su séquito de Musas. ¿Acaso no se necesitan mutuamente eros y poesía? (58). La conjunción de la faceta apolínea con la dionisíaca puede ser tal vez el recurso eficaz para salvar la distancia entre dialéctica teológica y rito teúrgico.

W

La Teología misma adopta, en el decurso del platonismo, el carácter de una ciencia que prepara al Alma para la contemplación divina, vía filosófico-catártica que bien puede llamarse 'religio mentis' (59). Cuando la Antigüedad agonizaba, y hacía su aparición el Cristianismo, las escuelas de filosofía buscaban desesperadamente este remedio: 'la religión de la mente'. La trayectoria toda del platonismo, en la que seguramente bebió Dionisio, está acompañada por la inquietud de ahondar en los temas teológicos, como vía de conocimiento perfeccionador y unitivo:

"En todo tiempo, Protarco -dice Platón-, mi temor, al pronunciar los nombres de los dioses, no es un temor humano sino que está por encima de los mayores temores" (60).

Y Plutarco (s. II d. C) en De Isis et Osiris, el sacerdote-filósofo, agrega:

"Entre todos los bienes que son propiedad natural del hombre, ninguno es tan divino como la palabra, sobre todo aquella que se dirige a los dioses, y ninguno tiene acción tan decisiva sobre su felicidad".

Por eso:

"En la fiesta en honor de Hermes, los egipcios comen miel e higos, diciendo 'Dulce es la verdad'”.

(57) HERMIAS ALEXANDRINUS, In Platonis Phaedrum scholia, (Couvreur), Paris, 1901 (Hildesheim, 1971), 98-90.

(58) "In actual fact, the schema of four modes of theological exposition is clearly in the main a heuristic device which conceals a very complex situation where the much-cited principle of 'everything in everything but appropriately in each case' (panta en pâsin, oikeiôs de en hekastôi, El Th. 103) seems to be operating even in methodology". GERSH, en PTP, p. 22.

(59) "D'autre part, on voit que cette connaissance mystique a pris la place des statues de culte des dieux, des himnes qu'on leur adresse et de tout le culte lui-même. Dès lors, lire le Parménide devient l'acte religieux par excellence, et la véritable purification rituelle est devenue la pratique des vertus philosophiques, qui constitue le vraie service religieux. Célébrer la divinité en faisant de la théologie scientifique, tel est l'idéal du philosophe néoplatonicenne. Lire le Parménide c'est chanter un hymne à Dieu. La celebration de la divinité est tout intellectuelle, c'est la religio mentis"., SAFFREY en PROCLUS, Hymnes et prières pp.15-16.

(60) To d'emon deos, ô Prôtarche, aei pros ta tôn theôn onomata ouk esti kat' anthôpon, alla pera tou megistou phobou. PLATÓN, Filebo $12 \mathrm{c}$. 
La ciencia teológica es una introducción en los Misterios, para los hombres de esta época, como lo dice explícitamente Plutarco:

"El verdadero Isíaco (o sea el iniciado en los Misterios de Isis) es aquel que habiendo recibido, por la vía legal de la tradición, todo cuanto se enseña y practica relativo a estas divinidades, lo somete al examen de la razón, y se esfuerza, por medio de la filosofía, en profundizar toda la verdad".

El hombre -piensa Plutarco- mediante la búsqueda incesante del saber acerca de lo divino - puede conquistar aquella vida, que proporciona la inmortalidad y la felicidad eternas porque:

"Desear la verdad es aspirar a la divinidad, sobre todo la verdad referente en lo concerniente a los dioses.

Debemos aplicarnos principalmente sobre todo al conocimiento de los dioses, con toda la capacidad humana, rogándoles se dignen concedérnoslo -dice Plutarco-. La verdad es lo más grande que puede obtener el hombre; la verdad es lo más augusto que puede conceder la divinidad.

Dios cede todos los bienes a los hombres para subvenir a sus necesidades; pero al comunicarles la inteligencia y la sabiduría les permite sean partícipes de los atributos que le son propios... La divina felicidad no consiste ni en plata ni en oro; ni su poder está fundado en el trueno o el rayo, sino en la ciencia y en la sabiduría (...)".

Un platónico posterior, Juliano (s. IV d. C), el emperador que anheló restaurar la piedad a los antiguos dioses, exclama:

"Que me asistan en este caso Hermes, dios del verbo, con las Musas y Apolo Musagete, que preside también la elocuencia. Que me hagan proferir todo lo que los dioses aprecian que se diga y crea sobre ellos" (61).

En este marco se desenvuelve la obra del anónimo autor del Corpus. Así dice Dionisio:

“...si no hubiésemos captado con la inteligencia que no hay que desatender el conocimiento accesible de las cosas divinas... de ninguna manera habríamos marchado hacia eso, con extraordinaria piedad. Y de esto nos persuadieron no solo las tendencias naturales de las inteligencias, que siempre anhelan eróticamente la contemplación permitida de lo supranatural, sino también la óptima disposición misma de las divinas normas..." (III.3). “...todo lo divino, y cuanto nos ha sido revelado, es conocido con la sola participación” (II.7).

(61) All'emoige toutou parastaie boêthos ho te logios Hermês zyn tais Mousais ho te Mousêgetês Apollôn, epei kai autôi prosêkei tôn logôn, kai doien de eipein hoposa tois theois phila legesthai te kai pisteuesthai peri autôn. JULIANO EMPERADOR, Discurso sobre de Helios - Rey. 132 a-b. 
"Ya que, si de algún modo es necesario creer en la totalmente sabia y veracísima Teología, se descubre y se ve contemplativamente lo divino, de manera proporcional a las inteligencias de cada uno" (I.1.).

El primer capítulo de $D N$, atribuido a Dionisio del Areópago, es un bello exponente de la búsqueda de la verdad acerca de lo divino, según una síntesis, que asume las tensiones y polémicas que suscita la temática misma. ¿Sobrepasa el rito al mito, o no? El objeto del tratado sobre los Nombres aparece envuelto por un tejido de sutiles referencias, que hilvanan un verdadero nudo a desentrañar. Como un laberinto, pleno de enigmas, va desgranando el núcleo temático, para destacar el skopos, la intención del libro.

El primer capítulo en el tratado sobre los Nombres Divinos cumple la función de un prólogo, procedimiento típico de la escolástica neoplatónica. Una de las características de los escritores neoplatónicos, notoria principalmente en los comentarios, sea de Platón o de Aristóteles, es la importancia otorgada a los prólogos. El universo, contenido dentro del libro, está, a su vez, encerrado en la apretada presentación preliminar del objetivo (skopos) perseguido, expuesto en el prólogo como síntesis seminal de la totalidad. En definitiva: universo, libro, prólogo, expresan, bajo una forma u otra, lo mismo: la destinación del alma, cumpliendo el ciclo de retorno a la Fuente. O sea: circularidad de monê, proodos, epistrophê (permanencia estable, desarrollo y recapitulación en la unidad), circularidad anunciada por la completitud del todo encerrada en la estrechez del prólogo que anticipa, concentradamente, el núcleo germinal.

Dionisio considera a la divinidad de modo explícito como 'supraesencial', esto es: más allá de Ser e Inteligencia. Ante un objeto de tales características solo puede haber 'ciencia supraesencial', como la llama Dionisio.

Veamos ahora los puntos salientes del contenido del capítulo I, en forma resumida:

1. El objetivo del libro es la explicación de los Nombres Divinos.

2. La explicación está sujeta a la 'norma de los Oráculos (Logia)', contraponiendo las palabras persuasivas de la sabiduría humana a la demostración de los teólogos.

3. De lo divino puede haber solo ciencia supraesencial: esto es la veracísima teología

4. La teología proporciona la visión epóptica de lo divino

5. Solo conocemos de Dios aquello que Dios dice de sí mismo. Por consiguiente considerar y ocuparse de lo revelado por Dios mismo es ciencia y contemplación (episteme y theoría)

6. La visión obtenida a partir de dicha ciencia y contemplación es kata analogian, o sea proporcional a la capacidad de cada uno.

7. La Thearchía (Principio de divinidad) es principio iniciático de los iniciados (tôn teloumenôn teletarchia)

8. Se alaba a la Thearquía, tal como ella se ha donado a sí misma, en el interior de la tradición (paradedôken) acorde a los Sagrados Oráculos (hierois 
logiois), iluminados (phôtizomenoi) en todo lo que se refiere a los himnos theárquicos (pros tous thearchikous hymous)

9. Cuando se recibe la impronta de la sacra himnología (pros tas hieras hymnologias typoumenoi) se vuelven visibles las luces theárquicas (thearchika phôta)

10. Este proceso es una iniciación en los Logia (pros tôn theiôn logiôn memyêmetha), de acuerdo con las benefactora procesión de la Thearchía (pros tas agathourgous tês thearchias proodous)

11. El tratamiento teológico permite ver a la Thearchía, alabada con himnos, de acuerdo con las denominaciones divinas

Este capítulo es un verdadero microcosmos literario, con múltiples referencias $\mathrm{y}$ alusiones que solo comienzan a significar una vez desplegadas, en virtud de los campos referenciales denotados. Cuando las alusiones cobran su pleno significado se empieza a abrir un vastísimo ámbito, hasta ese momento aludido apenas. Dionisio va delineando su punto de vista, elaborado dentro del corazón mismo de las discusiones escolares, usando del vocabulario iniciático a lo largo de las idas y vueltas de sus reflexiones.

Tras los Nombres Divinos resuena la exégesis, desarrollada por la Escuela de Atenas, del diálogo Parménides de Platón (62). En la Teología Platónica y en el Comentario al Parménides, Proclo resume un modo escolar de lectura del diálogo, que resultó constitutivo del denominado 'neoplatonismo' (63). DN se presenta como una culminación de esa temática en la Antigüedad clásica y como un verdadero inicio dentro del ámbito cristiano (64).

El saber de lo divino, la 'teología', mediante el tratamiento de los Nombres Divinos, en tanto vía afirmativa, sumada a la vía negativa, que Dionisio llamó, por primera vez -creando una espléndida expresión- 'teología mística', apuntan a la contemplación unitiva, fin perseguido a través del conocimiento mismo.

Theoría (contemplación) y henosis (unión) son dos caras de un mismo problema: la aspiración humana a religarse con lo divino. Núcleo de la problemática dionisíaca, (núcleo) íntimamente vinculado con Proclo, el maestro platónico de Atenas, diadochos (continuador, sucesor) de la Academia, como se presentaba a sí mismo.

En Theol. Plat. (1.29) Proclo confirma la aplicación de la exégesis del Parménides platónico a la cuestión de la nominación divina. La primera hipótesis del Parménides excluye todo nombre del Uno, pero en la segunda hipótesis se establece nombre y tratamiento racional (onoma kai logos) para el Uno de la segunda hipótesis.

"Para decirlo brevemente, todos los principios de la ciencia teológica (ta tês theologikês epistêmês axiômata) aparecen de una manera perfectamente clara en ese

(62) "Pero si es necesario de modo pleno tener ante los ojos en un solo diálogo de Platón la teología en su totalidad y de modo integral, parecerá quizás que se dice una paradoja, que solo resultará evidente para quienes son de nuestra familia espiritual (tês êmeteras hestias) pues se trata del Parménides". PROCLO, Th. Plat. I. 7. 15-16.

(63) SAFFREY, Recherches sur le néoplatonisme après Plotin, Paris, 1990; SAFFREY-WESTERINK, Introduction a Livre I de PROCLUS, Théol. Plat., Paris, 1968.

(64) CORSINI, Il trattato 'de Divinis Nominibus'dello Pseudo-Dionigi e I commenti neoplatonici al Parmenide, Torino, 1962. 
diálogo (el Parménides) -en él se encuentran todos los mundos divinos (tôn theiôn diakosmoi pantes) de acuerdo a la continuidad de su llegada a la existencia-, pues no contiene otra cosa que no sea el canto del himno de la generación de los dioses (theiôn genesis hymnêmenê (65)) y de todo lo que existe, sea lo que fuere, a partir de la causa inefable e incognoscible del universo" (66).

Proclo reúne en este párrafo el carácter axiomático de la ciencia teológica con la celebración hímnica a los dioses (67). La segunda hipótesis del Parménides resulta un 'himno a la generación de los dioses' (68) como la primera hipótesis es exaltada como un 'himno teológico' ofrecido al Uno (69). La conjunción en Proclo de la ciencia con la elevación de himnos de alabanza es compartida por Dionisio, en estrecha continuidad de su modelo.

Ahora bien, los nombres de los dioses son, para Proclo, de tres clases:

1) Nombres propiamente divinos;

2) Nombres demónicos, que pertenecen al ámbito intelectivo (noerôs), homoiôma de los nombres divinos;

3) Nombres logikôs, eikona en kinêsei de visiones interiores (tôn endon theamatôn). Esta tercera clase de nombres es el resultado de la ciencia (hê par'hêmîn epistême) que fabrica similitudes de las realidades (tôn te allôn pragmatôn homoiômata), por medio del discurso (dia logou), así como el Intelecto demiúrgico produce eidôla temporales de las Ideas eternas. Cada nombre hace nacer como una estatua (agalma) de los dioses.

Por tanto, la ciencia teológica, que indaga y expone la vía afirmativa de los Nombres Divinos, recrea con la palabra un cosmos reverencial y glorificador de la Sacratísima Thearchía.

Se remonta la preocupación por los 'Nombres Divinos' hasta el Cratilo de Platón, donde el heraclíteo Cratilo sostiene el carácter natural (physei) de los nombres; el socrático Hermógenes, la convencionalidad (thesei), en tanto Sócrates dirime el tema sosteniendo que algunos nombres son physei y otros thesei (70).

En In Parm (71) está sintetizada la opinión de Proclo, mil años después de la controversia nombres 'naturales' vs. nombres 'convencionales' del Cratilo:

(65) A pesar de que FESTUGIÈRE en 'Notes critiques sur Théol. Plat. I' ( en PTP, p. xxxii) considera que 'hymnein' debe traducirse 'exponer', discrepo con esta opinión y comparto la traducción de los editores. Cf. GERSCH, 'Proclus'Theological Methods' (en Ibid. p. 22).

(66) PROCLO, Th. Plat. I.7.15-17.

(67) Según SAFFREY-WESTERINK, en la 'Introducción a Théol. Plat.I' (p. 1xxii) Proclo alude a una práctica definida del culto en época imperial: un celebrante llamado 'teólogo' hacía una especie de homilía en prosa o en verso llamada 'teología', elogio solemne en honor del dios. Así, en un epigrama ático sobre el 'teólogo' Laetus (s.III d,C) se llama 'himnos' a sus exposiciones filosóficas.

(68) DAMASCIO (In Parm. II.247.118; 370.221) recoge la tesis de Proclo acerca de que en el Parménides 'Platón se propuso escribir una teogonía'.

(69) Cf. PROCLO, In Parm. VII.1191.

(70) Cf. PROCLO, In Crat. (Pasquali) p. 4.

(71) PROCLO, In Parm., IV. 849-852. 
“(851) Si los nombres son imágenes en palabras de los objetos a los que se aplican (agalmata tôn pragmatôn logika), se refieren en primer término (prôtôs) a las ideas inmateriales (tôn aülôn eidôn) y, de modo derivado (deuterôs), a las cosas sensibles (tôn aisthêtôn), puesto que estas cosas derivan tanto su esencia (tên ousian) como su designación (tên epônymian) de allá (ekeithen) (...).

Platón usa los nombres 'homónimamente [Cf. Aristóteles, Categ. , c.1] al designar de la misma manera lo inteligible y lo sensible, ...pero no de modo ambiguo (hôs onoma psylon) aplicando un mismo nombre a dos cosas diferentes sino como un nombre que es, en primer lugar, una semejanza (aphomoiumenon) de la realidad inteligible $\mathrm{y}$, en segundo lugar, de la cosa sensible (...). En un caso es una imagen (eikôn) de un objeto divino (theiou pragmatos) y en el otro una semejanza de un individuo sensible (aisthêtou). (852) ...por un lado es una imagen de un paradigma (paradeigmatos eikôn), por el otro, imagen de imagen, ídolo de un ídolo (eidôlou eidôlon) (...).

Así como el ser pertenece a lo menos auténtico por derivación de una instancia más genuina, así también los nombres de cosas secundarias provienen de nombres de seres superiores a ellos (...). Usamos los nombres para significar distinciones en el pensamiento entre las cosas (tas diakekrimenas pèri tôn pragmatôn ennoias) y, para la distinción y la pureza sin mezcla, propias del reino más elevado, usamos, en primer término, los nombres que son apropiados para las Ideas pero no para las cosas que contienen una considerable mezcla de cualidades opuestas (...).

Los nombres refieren primero a las Ideas inteligibles (epi tôn noêtôn eidôn) mientras los objetos sensibles toman su nombre, conjuntamente con su ser, de esa fuente. (853) Esto corresponde a los nombres que están al alcance de la contemplación (theôrein) de nuestra alma.

Hay una gradación en los nombres, como la hay en el conocimiento (gnosis): theia, angelika, daimonia, anthrôpina. Unos, pronunciables (rêta); otros, impronunciables (arrêta). Como enseñó el Cratilo (391 a), y antes una tradición divinamente inspirada (hê entheos paradosis), tanto el conocimiento como el dar nombres (gnosis kai onomasia), entre los dioses, trasciende y difiere del modo utilizado por nosotros".

Para Damascio (72), aquello que es 'anónimo por naturaleza', el Uno no expresable con el discurso, solo puede ser referido mediante nombres utilizados como 'símbolos'. Después de cerrar los ojos (myei) para entrar en el mysterion, la gnosis se vuelve unificación (gignetai anti gnôseôs henôsis).

El tratamiento teológico de los Nombres Divinos, según Dionisio, no puede apartarse de la revelación verdadera que Dios ofrenda acerca de sí mismo. La com- 
prensión de los 'Oráculos' (logia) -palabra usada permanentemente por Dionisio, presumiblemente para referirse a las Sagradas Escrituras- (la comprensión de los Oráculos) requiere la vigencia de una tradición interpretativa, de acuerdo con ciertas reglas que acompañan a la Revelación. Todo ello en estrecha dependencia de Dios mismo, pues es Él quien establece el canon o la normatividad que guía la exégesis.

"No hay que osar decir ni reflexionar algo acerca de la divinidad supraesencial y oculta -dice Dionisio- más allá de lo manifestado a nosotros, por vía divina, a partir de los Sagrados Oráculos. Pues sería desconocimiento de su supraesencialidad por encima de razón, inteligencia y esencia. En relación con la (divinidad) hay que aplicar la ciencia supraesencial, alzándonos sobre lo escarpado, tanto cuanto el rayo de los Oráculos theárquicos lo conceda, dirigiéndonos hacia los esplendores superiores, con la prudencia y sacralidad que rodea a lo divino" (73).

En ese proceso la teología engloba lo dicho de Dios, por Dios, además de los cánones para penetrar en los ocultos designios divinos. La teología se conforma como un camino de acceso, entregado (74). La circularidad, ya se sabe, es un signo característico de la concepción neoplatónica: el Principio se despliega y retorna sobre sí mismo, de acuerdo con un ritmo de mone, proodos, epistrophe, permanencia, salida de sí y vuelta al origen. Este ciclo se cumple a través de la tensión que moviliza al Alma, cuando anhela conocer y aproximarse íntimamente a su propio Principio, buscando unirse a él, eliminando toda distancia y apartamiento.

La divina palabra oracular resplandece a través de los himnos de alabanza, con los que se canta la Luz irradiada desde Dios, en virtud de la misma Luz divina que envía su gracia. No hay duda que la valencia de los 'himnos theárquicos' se manifiesta en su misma operatividad.

"Pues es necesario que nos elevemos hacia (la divinidad), como principio de bien, primero con oraciones, y que, aproximándonos más a (la divinidad), a través de esto, nos iniciemos en lo que respecta a los dones -totalmente buenos- asentados en torno de ella. Pues de hecho ella está junto a todo, no todo está junto a ella. Entonces, cuando la invocamos con oraciones totalmente puras, con inteligencia expedita y con predisposición hacia la divina unión, estamos entonces también nosotros junto a ella. Pues (la divinidad) ni siquiera está en un lugar, como para que se aparte de algo o transite de unas cosas hacia otras. (...) Levantémonos entonces con oraciones -dice Dionisio- hacia la muy alta ascensión de los rayos divinos y buenos, como si (hubiera) una multiluminosa cadena, suspendida del celestial extremo que, al descender hacia aquí, cuando nos tomamos de (esta cadena) con manos alternadas siempre

(73) Pseudo DIONISIO AREOPAGITA, $D N$, I. 1.

(74) ROQUES, R. Note sur la notion de Theologia chez le Pseudo-Denys l'Aréopagite, $R$. Asc. et Myst. 25 (1949), 201-212; De l'implication des methodes theologiques chez le Pseudo-Denys, ibid. 30 (1954), 267-274. 
hacia adelante, pareciéramos tirar de ella hacia abajo pero en realidad no la hiciéramos bajar, al moverla hacia arriba y hacia abajo, sino que nosotros mismos nos eleváramos hacia los muy altos resplandores de los rayos multiluminosos (Cf. Homero, Ilíada 8. 18-20). O como si, subidos a una nave y asiéndonos de las amarras tendidas desde una roca hacia nosotros y entregadas a nosotros para tirar de ellas, lleváramos no la roca sobre nosotros sino en verdad a nosotros mismos, y a la nave, sobre la roca. Como también si alguien, por el contrario, parado sobre la nave ha de empujar una roca costera, nada hará contra la roca parada e inmóvil, sino que uno se apartará a sí mismo de ella, y cuanto más la empuje más será lanzado lejos de ella. Por esto también, en favor de todo y en mayor grado en favor de la teología, es necesario que comencemos por la oración, no como atrayendo la fuerza que está en todas partes y en ningún lugar, sino como poniéndonos nosotros mismos en sus manos y uniéndonos a ella con las divinas menciones e invocaciones" (75).

Con la oración, o sea el canto de los himnos sacros (76), nos encontramos de lleno ante el componente de la teología, que opera teúrgicamente, pues es una cadena luminosa, circulación constante, por la que Dios desciende y vuelve a ascender, según una actividad puramente divina, que nos arrastra (77). Teurgia es, ni más ni menos, toda operación realizada por Dios mismo. La Encarnación divina es -para Dionisio, como vimos- la obra teúrgica por excelencia.

La razón que hace de la himnología una conjunción de demostración y símbolo, de ciencia y operación es proporcionada por Proclo (78). El conocimiento científico cuando plasma los nombres divinos como imágenes (tôn theiôn eikonas) de los dioses actúa de manera teúrgica, sostiene Proclo. La epistêmê es equivalente al procedimiento teúrgico que consiste en operar mediante ciertos símbolos. Los símbolos, herramienta teúrgica por excelencia, favorecen la invocación de los dioses. Al recurrir a los símbolos, el proceso teúrgico ocurre a través de la iluminación (ellampsis) divina de estatuas fabricadas artificialmente (tên technêtôn agalmatôn). Acontece un proceso similar, afirma Proclo, cuando se ejercita la ciencia intelectiva acerca de lo divino (he noera tôn theiôn epistêmê). La ciencia acerca de los dioses es ella misma teúrgica. Pues todo proceso cognoscitivo utiliza un medio inerte al que reanima para que fructifique. Al conocer se pone en práctica también aquella conexión teúrgica que hace presente los dioses, en cualquier medio, incluso el medio más apartado de lo divino. De modo similar, en el saber que nombra a los dioses, la composición y la división de los sonidos articulados (synthesesi kai diairesesi) revela el ser oculto de los dioses (ekphainei tên apokekrymmenên ousian tôn theôn) (79). Proclo señala con todo cuida-

(75) Pseudo DIONISIO AREOPAGITA, DN, III. PERCZEL muestra la aplicación de la imagen de la cuerda hecha por San Simeón a su propia experiencia de vida, en 'Denys l'Aréopagite et Syméon le Nouveau Théologien' (en $D A P$, p. 350).

(76) Cf. Pseudo DIONISIO, EH 3.3.7 Migne, $P G$ 3, 436 C-D.

(77) Cf. RITACCO de GAYOSO, 'La eudaimonía y las bienaventuranzas', Sapientia, 49 (1994) 193-4, p.201-215; PROCLO, In Tim. I.212 sobre la oración.

(78) PROCLO, Th. Plat. I, 29.

(79) RITACCO de GAYOSO, 'De Proclo a Dionisio Areopagita: Prometeo y Epimetheo', Diadoche 12 (1998), 55-82. 
do de qué manera la efectividad teúrgica resulta operativa en diversos niveles, comportándose en cada nivel de manera adecuada al rango correspondiente. Por lo tanto, la actualidad del momento teúrgico alcanza su cumplimiento también en el ámbito puramente dialéctico-demostrativo de la teología.

En consonancia con esto, Dionisio insiste en reflejar la potencialidad activa del Nombre en el interior de la consideración teológica. Cada uno de los nombres es una vía de acceso a lo Inaccesible, donación hecha por Dios mismo. Ahora bien, la nominación divina remite a la pregunta por el carácter científico o no, de ese tratamiento.

Por ello, el tratado sobre los Nombres (I.1) comienza estableciendo una clara oposición entre quienes se ocupan de la cuestión de los nombres con razonamientos y conclusiones en el ámbito de una ciencia simplemente a nuestro alcance, 'meras palabras persuasivas de la sabiduría puramente humana', y quienes, por el contrario, se atienen en todo a un desarrollo a partir de la donación divina misma, que hace posible una demostración verdadera (80).

Dionisio usa la palabra 'demostración' (apodeixis) para referirse a la explicación sostenida por la gracia divina, o sea utiliza el término que denomina el recurso aristotélico por excelencia para la producción de una prueba científica que garantice la verdad de lo expuesto. Se trata de la prueba deductiva mediante el silogismo (81). Proclo también utiliza con frecuencia el término aplicado a una explicación probatoria deductiva (82). Platón (83), a su vez, alude con 'apodeixis' a una prueba que utiliza sobre todo palabras, es decir, la argumentación como elemento probatorio.

Un planteo en términos muy similares aparece en el Comentario al Parménides de Proclo. Se trata casi con seguridad del contexto evocado por Dionisio.

Los 'nombres' divinos son mencionados por Proclo (84) explícitamente dentro del contexto de una demostración científica (di'apodeizeon). Es científica en la misma medida en que confirma cada una de sus afirmaciones ( $t a$ apophantikoteron) con logismoi (razonamientos) que se puedan encadenar causalmente y justificar lo dicho. La similitud con Dionisio es notoria. Además, Proclo en este caso conecta los modos de la locura apolínea (mantikê- poiêtikê), tomados del Fedro platónico, con la hermenéutica de los nombres llevada a cabo por los Poetas, la Escuela Eleática y, de manera definitiva, por la dialéctica de Platón. Los diálogos platónicos: Fedro, Sofista y Parménides son el despliegue filosófico del camino inspirado por Apolo y las Musas.

Esa misma vía mántico-apolínea de aproximación a lo divino a través de los Nombres, es vinculada por el A. del Corpus, con la demostración exaltada por la presencia del Espíritu, que moviliza la comprensión de los teólogos. El peso de la prueba está dado por el divino thesmós, la norma, predefinida por los Oráculos mismos, respecto de la verdad acerca de Dios. La demostración de los teólogos, inspirada por el Espíritu, está sostenida por aquella dynamis, fortaleza divina, capacidad inextinguible que habilita para coligarnos "a lo impronunciable e ignoto, im-

(80) COULOUBARITSIS, Le sens de la 'demonstration' chez le pseudo-Denys, Byzantinische Zeitschrift 75 (1982) 317-335.

(81) ARISTÓTELES, An. Post. 71 b 17.

(82) PROCLO, El. Theol. prop. 22, 111, 176.

(83) PLATÓN, Thaet. 162 ; Phaed. 73 a, 92 d.

(84) PROCLO, In Parm. I. 646-647. 
pronunciable e ignotamente, según la unión más fuerte que el poder y la actividad lógica e intelectual en nosotros" (85). Las demostraciones en que se apoya Dionisio están garantizadas por el despliegue divino en la Revelación.

La teología resulta, por lo tanto, inseparable de la palabra sacra, que fue llamada por los griegos venerables 'mito'. En el mito alcanza su cumplimiento el entrañable vínculo de la teurgia con la teología.

Lo que Dios ha dicho de sí conforma un elaborado cosmos mítico, como palabra verdadera, que por su íntima articulación y coherencia es un universo, si bien 'universo de discurso', un ser vivo y latente, un mundo regulado y armónico. El alma, para apropiarse y afincarse en ese cosmos, ha de prepararse adecuadamente.

El amigo y confidente de Juliano, Salustio, ya había ahondado en la comparación del cosmos visible con el cosmos mítico, convencido de que todo conocimiento es asimilativo con su objeto. Escribió un manual encantador "Sobre los Dioses y el Mundo" para instrucción de quienes se interesen por saber algo sobre los dioses -uno de los dioses es el mundo- con el fin de asemejarse a los dioses a través de lo aprendido.

Una simpatía imitativa de todo con todo reina entre los dioses y los hombres. Quien se disponga a escuchar acerca de los dioses debe estar suficientemente preparado para consolidar en sí mismo la adecuación con las enseñanzas (logoi) divinas. El procedimiento purificatorio consiste en una vida virtuosa, orientada sin declinación hacia la verdad. Los logoi referidos a los dioses, dignos de ellos, son portadores de una semejanza con los dioses, que los vuelve tan divinos como los dioses mismos. Sacralidad que se dispensa graciosamente a todo aquel que declame esos logoi, recuerda Salustio (III). Por todo ello, el mito es el vehículo adecuado para la reproducción de la naturaleza de los dioses por medio de las palabras. Ellas son el medio más apropiado para encaminarnos hacia lo divino. En el mito lo invisible se vuelve visible y lo indecible es representado de acuerdo con lo que puede ser divulgado (III.3).

Al presentar lo mítico de esta forma, Salustio saca a luz la homoiôsis subyacente entre el relato, su significado, el universo y el iniciado mismo, que se asimila al mensaje enunciado, mientras lo pronuncia. Y más aún, la semejanza se hace extensiva al proceso interpretativo elaborado por el filósofo, quien resulta iniciado (86) por esa misma comprensión intelectual. (III. 4). Lo más sugerente y enriquecedor del mito corresponde a la suscitación en nosotros de un impulso de búsqueda. Frente al mito nos sentimos obligados a investigar (zêtein), piensa Salustio. Por ello, la dianoia (el razonamiento), no puede permanecer de ninguna manera inactiva ante el mito.

Usaron mitos:

1) los poetas inspirados (theolêptoi) por los dioses;

2) los mejores filósofos;

(85) Pseudo-DIONISIO AREOPAGITA, DN, I.1.

(86) La filosofía como la verdadera iniciación en los Misterios puede verse en THEÓN de ESMIRNA, comentado en RITACCO de GAYOSO, 'El Medioevo como encuentro de tradiciones', Epimeleia 5-10 (1996), 239-257. 
3) los iniciados (tas teletas), y

4) los dioses mismos en los oráculos (en chrêsmois). (III.1).

Qué objeto más noble y más apropiado puede tener la filosofía como no sea la indagación de los mitos, principalmente para esclarecer en ellos lo que efectivamente dicen sobre los dioses (Dia ti de theioi hoi mythoi philosophias zêtein). (III.2).

La propuesta de Salustio es un programa de indagación de la mitología que fue puesto en práctica por platónicos, en particular, Proclo. Este programa señala además la dirección tomada por Dionisio con la exploración del significado de la nominación divina.

Un tiempo antes de Salustio, Plutarco, ya había proporcionado una importante indicación al asegurar que el momento dialéctico, sustentado por la vía afirmativa y la negativa, está ceñido a la dimensión 'simbólica' del nombre:

"Esta razón única que regula o rige el universo, esta única providencia que lo gobierna -dice Plutarco- y esas potencias destinadas a ayudarle en todo, son objeto de homenajes y denominaciones que varían con la diversidad de costumbre. Esos diversos nombres y ritos sirven de símbolos, unos más oscuros, más claros otros, para aquellos que se consagran a los estudios sagrados”.

Y advierte:

"Los filósofos tienen razón al decir que aquellos que no aprendieron a conocer el sentido exacto de las palabras se equivocan igualmente cuando se trata de servirse de las cosas".

La dialéctica, al ocuparse de los nombres, prepara para:

"La visión del Ser que es inteligencia, luz, santidad, como relámpago que brilla a través de nuestra alma, (y que) no puede obtenerse jamás ni percibirse más que una sola vez. Por eso Platón y Aristóteles dan a esta parte de la filosofía el nombre de epótica o contemplativa. Con ello quieren darnos a entender que aquellos que hubieren franqueado, ayudados por la razón, la mezcla confusa de toda clase de opiniones, y se lancen hacia ese Ser primero, simple e inmaterial, consiguen llegar sin intermediario a la pura verdad que está a su alrededor, y creen haber alcanzado con ello el fin supremo de la filosofía, como ocurre durante la iniciación".

La dialéctica, por tanto, es un camino de iniciación, en el que confluyen la vía afirmativa y la negativa, el momento apolíneo y el dionisiaco, pues alcanzar la verdad es revelación y donación de Dios mismo.

Se ha conservado hasta nosotros un breve tratado en lengua griega llamado "Prolegómenos a la filosofía de Platón", probablemente de época contemporánea al pseudo Dionisio. Fue hallado en una copia perteneciente a la biblioteca de Arethas de Cesarea (s. X d. C.).

Resume bellamente, de acuerdo a las pautas dejadas por Jámblico (s. IV) y Proclo (s. V), los rasgos salientes de la escolástica elaborada por los diadochoi 
(académicos sucesores de Platón) de la Escuela de Atenas. Los Prolegomena ofrecen la división de los diálogos de acuerdo con el orden de lectura organizado por Jámblico para elevar el alma mediante la adquisición de las virtudes.

Este encantador anónimo -escrito por algún platónico alejandrino del s. VI d. C.: Olimpiodoro, Elías u otro- es una presentación de la estructura orgánica que sostiene al conjunto de los diálogos platónicos según la perspectiva sistematizadora de los últimos platónicos de Atenas.

Una estupenda comparación atraviesa la totalidad del Anónimo: el diálogo platónico es como el universo (ho diálogos hoion kosmos estin) (87). Platón al escribirlos imitó la obra creada por Dios, Platón imitó el universo con toda su variedad y despliegue de formas (mimoumenos oun ta theia dêmiourgêmata, ton kosmon legô, kai touto epoiêsen). El universo mismo es un diálogo (ho kosmos dialogos estin).

Dijo lo mismo Platón:

“... todo discurso debe estar compuesto como un organismo vivo, con un cuerpo propio, de forma que no sea acéfalo, ni le falten los pies sino que tenga una parte central y extremidades, escritas de manera que se correspondan unas con otras y con el todo”. (Versión de L. Gil Fernández modificada) (88).

Toda obra literaria es análoga a un ser viviente, de modo que la más bella de las obras literarias imitará al más hermoso de los seres vivientes. Como el viviente más bello es el universo, todo diálogo es comparable y resulta proporcionado con el universo, el diálogo posee por ello la forma literaria más perfecta (89).

La habilidad y destreza consumadas de Platón tanto en el manejo del arte de debatir (dialegesthai) -es decir el arte dialéctico- como en el arte del amor (ta erôtika) y el arte de dar a luz (tên maieian) son una prueba de que Platón se mantuvo alejado de las tesis escépticas (90).

El arte de la división, es decir la parte principal de la dialéctica, es un don divino para los hombres (tên diairesin kai dosin einai tois anthropois phêsin ek theôn dia Promêtheôs) (91). Fue traído, junto con el fuego, por Prometeo (92).

Los tres artes: Dialéctica, Erótica y Mayeútica, glorifican a Dios, como 'agathos', 'kalos', 'sophos', calificativos tomados del Fedro (246 e):

(87) SCAZZOSO, en 'La terminología misterica...' (p. 415, nota 18) refiere cómo Máximo el Confesor explica alegóricamente la Ecclesia pseudo-dionisiana como un misterio extraordinario que comprende todo el cosmos. Véase también GOLITZIN, op. cit.

(88) PLATÓN, Fedro 264 c: dein panta logon hôsper zôion synestanai sôma ti echonta auton hautou, hôste mête akephalon einai mête apoun, alla mesa te echein kai akra, preponta allêlois kai tôi holôi gegrammena. Cf. PROCLO, In Parm. I. 659; In Rep. I.6.

(89) ANÓNYMOUS Prolegomena to platonic philosophy (Westerink, ed.), Amsterdam, 1962; 4.15: legei ho Platôn, ho logos zôiôi analogei, oukoun kai tôi kallistôi tôn zôôn ho kallistos logos analogêsei; kalliston de zôion estin ho kosmos; toutôi de analogei ho dialogos,...; ho dialogos ara kallistos estin logos. Ibid. 9. 21.

(90) Una importante sección del Anónimo Prolegomena se ocupa con toda intención de refutar cualquier interpretación de Platón que pueda resultar próxima al escepticismo.

(91) Ibid. 9.23.

(92) PLATÓN, Filebo 16 c-d. 
"Pues del mismo modo en que la dialéctica atraviesa todas las ciencias, así también todas las cosas aspiran efectivamente al Bien, por ello (Platón) equipara al Bien con la dialéctica (têi dialektikêi tagathon). (Por otro lado) El arte del amor está en la esfera de la Belleza (têi erôtikêi to kalon), ya que amamos lo bello. (Por último) La sabiduría corresponde al arte de dar a luz (têi maieutikêi to sophon), puesto que así como la función del hombre sabio consiste en revelar lo que está oculto en las profundidades del alma y traer a la luz el fruto de sus esfuerzos, así también es el objeto del arte de la partera traer a luz el niño que está oculto en el seno materno" (93).

Los Prolegomena agregan, con el ánimo clasificatorio de los neoplatónicos, la siguiente correlación:

Bien- arte dialéctico

Belleza- arte erótico

Sabiduría- arte mayéutica

Bien, Belleza y Sabiduría, así como Dialéctica, Erótica y Mayéutica se complementan entre sí. Al quedar entrelazadas la ciencia dialéctica con la búsqueda amorosa, la resultante es la capacidad de engendrar que permite que lo divino mismo atraiga hacia sí por medio de un proceso anagógico.

W

Concluimos este recuento, que ha puesto en evidencia la eficacia y el valor expresivo de la palabra, con una tesis tentativa: hay una manera teológica de dirigirse a lo divino, en la que se combinan los aspectos teúrgicos del rito con el momento afirmativo y el negativo de la dialéctica, o sea el momento contemplativo con el unitivo, todo ello en un éxtasis iniciático: el himno theárquico concilia teología y teurgia.

En fin, según Dionisio (94), nada se puede decir de la Divinidad oculta, como no sea todo aquello que ella misma manifiesta bajo la forma de Sacros Oráculos. Por la vía oracular sabemos de ella que su ciencia y contemplación es impenetrable. Por eso, los teólogos le han cantado himnos como invisible, inaprensible, inexplorable, que no se puede investigar. Pero el Rayo supraesencial, sostenido por el Bien mismo, eleva las inteligencias hasta la contemplación (theôrían), la comunión (koinônian) y la asimilación (homoiôsis).

La luminosidad del Rayo contiene las inteligencias conmensuradamente, de acuerdo con la exaltación del brillo amoroso (tôi symmetrôi tôn themitôn ellampsê̂n erôti), elevándolas como si volaran (anaptepoumenous) -según lo permitido- en consonancia con la piedad.

Al honrar, con sagrada piedad de inteligencia y con prudente silencio, lo más oculto de la Thearquía, somos elevados más allá de los esplendores oraculares. A

(93) ANONYMUS, Prolegomena 2.11.

(94) Pseudo DIONISIO AREOPAGITA, $D N$, I. 
partir de allí, ya la Luz, con su misma iridiscencia, nos conduce (phôtagôgoumetha) más arriba todavía que los Oráculos, hasta los himnos theárquicos. Ahora son los himnos los que se imprimen (typoumenoi) en nosotros e irradian su propia luz (phôtizomenoi) y comienza así la alabanza del Principio de toda luz con himnos incesantes.

Acontece de esta forma la iniciación que inspiran los Oráculos (tauta pros tôn theiôn logiôn memyêmetha). Se desgrana entonces caudalosamente el himnario de los teólogos que dispone las denominaciones divinas bajo la forma de himnos de glorificación (hymnêtikôs) al manifestar las benefactoras procesiones de la Thearquía (tas agathourgous tês thearchias proodous).

La remotísima y oculta tradición (kryphia paradosis), proveniente de los Oráculos y secretamente interpretada, va proporcionando las otras luces teúrgicas, de modo gradual. Comienza por los símbolos, pasa luego a la contemplación inteligible (theoeidon noêsin) de la teofanía visible con luminosísimos resplandores similares a los de la Transfiguración, y por último deja que nos lancemos, según lo permitido, hacia el Rayo supraesencial. Acontece entonces la unión con la Luz y, en concordancia con esa unión, la gozosa alabanza con himnos incendiados (ellamphthentes) por la Luz supradivina (pros to hypertheon phôs henôsis). Estalla el cántico de himnos a la Providencia entonados por los enamorados de la verdad sobre toda verdad. Se le cantan himnos como 'sin nombre' y como 'a partir de todo nombre' y en la misma celebración hímnica los nombres configuran la luminosidad ígnea o de ámbar que ilumina a los iniciados en los Misterios (tous mystas).

Solo el círculo de Dios (Kyklôi theou), o sea los coros más próximos en torno a Dios (Serafines, Querubines y Tronos) disfrutan de la ciencia theárquica, afirma Dionisio (95). A su vez la teología, a través de la tradición, nos hace entrega de los himnos (96) (dio kai hymnous autês hê teología tois epi gês paradedôken) que irradian la luminosidad gozosa de la proximidad divina. Esos cánticos resuenan como la voz tumultuosa de las aguas (hôs phônê hydatôn, Ez. 1.24) especialmente cuando entonan la venerabilísima teología cantada como himno entre los himnos (tên polyumnêton kai sebasmiôtatên theologian):

"Hagios, Hagios, Hagios kyrios Sabaôth, plêrês pasa hê gê tês doxês autou. (Is. 6.3)" (97)

(95) Pseudo-DIONISIO AREOPAGITA, $\mathrm{CH}, 7.4, \mathrm{PG} 3.212 \mathrm{~b}$

(96) WITT, 'La fonction de la musique chez les contemporains du Denys authentique', Diotima, 23 (1995) 109-120: según el A., $\mathrm{CH}$ es uno de los libros más importantes para el estudio de la música cristiana. Es el producto del pensamiento platónico, representado por el círculo ateniense que rodeaba al primer obispo de la ciudad. La concepción de la liturgia que se gestó allí, prolongada por Clemente y Orígenes, consolidada en $\mathrm{CH}$, fue decisiva para el desarrollo de la música cristiana. La tradición helénica, con raíces en la choreia y el dithyrambo, favorecía la concepción mística de la danza terrestre, homóloga de la danza de los cuerpos celestes. La concepción jerárquica, que se remonta hasta el Timeo de Platón, favoreció que las asambleas eclesiales consideraran a los himnos como los cánticos propios de los ángeles, no meras imitaciones. FEDOROV en la Encyclopédie des Musiques Sacrées (Vol. 2, Paris, 1969) sostiene que $\mathrm{CH}$ es la base a partir de la que se desarrollará y se deformará la música de la Iglesia de Oriente, pero si abandonarla nunca del todo.

(97) De manera similar CIRILO DE JERUSALEM, Catequesis Mystagógica 5.6: "Nosotros recitamos esta doxología (el trisagion) que nos fue trasmitida por los Serafines, para participar de la hymnología de las armadas supraterrestres". La asamblea matinal, según JUAN CRISÓSTOMO (Homilía sobre Osias 1), resulta: "Un único coro, festivo y radiante, que canta los himnos a Dios, de manera armoniosa (symphônôs) y con la conciencia tranquila, como si proviniera de una única boca". 